\title{
The evaluation of ecological sustainable development capacities in Kashan: an historic city of Iran
}

\author{
N. Marsousi \& A. R. Lajevardi \\ Payame Noor University, Department of Geography, Iran
}

\begin{abstract}
This paper is trying to evaluate the ecological capacities of the environment for sustainable development in the urban sprawl of Kashan in its future developments. So we evaluate the land capacities as the most important ecological factor. Kashan is an historical city in Iran, which is famous for its Persian carpet manufacturing. It has experienced the sprawl growth in recent decades.

The methodology of this study is analytical-descriptive. The results show that: $67 \%$ of physical development of Kashan between the years 1938 to 2007 is caused by population growth, and $33 \%$ of it is due to sprawl growth. Also the existing Kashan land capacities can accept more than double of the existing population $(572,508)$. In other words, it can have 2.13 times population growth in the following 30 years with the same urban area.

Keywords: sprawl, urban land, ecological capacities, sustainable development, Kashan.
\end{abstract}

\section{Introduction}

Urban sprawl has been the most important barrier to urban sustainable development and that it prepares grounds for social unrest and insecurity [1]. Studies show that the cities with sprawl have suffered from greater losses when unexpected events have occurred [2]. Also the sprawl causes the density of the population distribution, requiring the need for much more services and authorities are forced to spend more for those services in comparison to the time when the city has the extensions in height and this makes the misdistribution of 
the services in the city, and basically there comes some weaknesses in this regard in a way that sometimes results in some dissatisfactions [3].

\section{Methodology}

For achieving our objective we have used Holdrn's model and the population prediction models.

The research methodology used here is a descriptive-analytical method.

\section{Discussion and findings}

\subsection{The appearance and physical growth of Kashan}

Functional changes in Kashan started in the third decade of the twentieth century, and have gradually appeared in the city's view after 1951. Rapid growth of urbanization started from $1961[4,5]$.

Table 1: Annual growth of population and extent of Kashan in the period of 1938 to 2006 [6].

\begin{tabular}{|c|c|c|c|c|c|c|c|}
\hline Year & 1938 & 1956 & 1966 & 1976 & 1986 & 1996 & 2006 \\
\hline Population & 46690 & 45955 & 58428 & 84863 & 138599 & 201372 & 248789 \\
\hline $\begin{array}{c}\text { Annual } \\
\text { population } \\
\text { growth }\end{array}$ & - & $-0 / 81$ & 2.43 & 3.8 & 5.02 & 3.8 & 2.13 \\
\hline extent & 500 & 700 & 900 & 1400 & 1800 & 5000 & 6000 \\
\hline $\begin{array}{c}\text { Annual } \\
\text { extent } \\
\text { growth }\end{array}$ & - & $1 / 88$ & $2 / 54$ & $4 / 5$ & $2 / 54$ & $10 / 75$ & $1 / 84$ \\
\hline
\end{tabular}

\subsection{Comparative analysis of urban land per capita gross in Kashan,} and some cities in the world

\subsubsection{Comparative analysis of urban land per capita gross in Kashan with some other cities of Iran}

For comparative analysis of urban land per capita gross of Kashan with other Iranian cities, 16 cities were randomly selected from among Iranian cities.

With a view of table 2 it is clear that: the average land per capita gross is higher in only two cities of Rasht and Yazd compared to Kashan. While the average land per capita gross in other cities studied, is lower than Kashan. The average land per capita gross is, in Tehran 40 percent, in Urmia 30 percent, in Ahvaz 94 percent, in Bandar Abbas 50 percent, in Kerman 95 percent, in Araq 42 percent, in Shiraz 61 percent, in Ekbatan 69 percent, in Ardabil 62 percent, in Zanjan 63 percent, in Qazvin 38 percent, in Sanandaj 50 percent, in Khorram Abad 41 percent and in Boroujerd 50 percent of the amount of per capita gross land in Kashan. 
Table 2: Comparison of urban land gross per capita in the cities of Kashan, compared with some other Iranian cities in 2006 [8].

\begin{tabular}{|c|c|c|c|c|}
\hline Name & Population & $\begin{array}{l}\text { The extent } \\
\text { to hectare }\end{array}$ & $\begin{array}{c}\text { Density } \\
\text { per hectare }\end{array}$ & $\begin{array}{l}\text { Per capita } \\
\text { gross land } \\
\text { for each } \\
\text { person } \\
\text { (Square } \\
\text { meter) }\end{array}$ \\
\hline Kashan & 248789 & 600 & $41 / 46$ & 241 \\
\hline Urmia & 577303 & 4200 & $137 / 45$ & $72 / 75$ \\
\hline Ahwaz & 969843 & 22000 & 44.04 & 227 \\
\hline Bandar Abbas & 367508 & 4500 & $81 / 66$ & $122 / 4$ \\
\hline Tehran & 77050306 & 73000 & $105 / 54$ & $94 / 7$ \\
\hline Rasht & 551161 & 13600 & $40 / 52$ & $246 / 75$ \\
\hline Shiraz & 1214808 & 17900 & $67 / 86$ & $147 / 25$ \\
\hline Ekbatan & 473149 & 7940 & $59 / 59$ & $167 / 81$ \\
\hline Kerman & 496684 & 11500 & 40 & $231 / 51$ \\
\hline Arak & 438338 & 4500 & $97 / 40$ & $102 / 66$ \\
\hline Ardabil & 412669 & 6200 & $66 / 55$ & $150 / 24$ \\
\hline Yazd & 423006 & 11000 & 40 & $260 / 043$ \\
\hline Zanjan & 341801 & 5250 & $65 / 10$ & $153 / 59$ \\
\hline Qazvin & 349821 & 3240 & 107 & 92.61 \\
\hline Sanandaj & 311446 & 3800 & $81 / 95$ & $122 / 01$ \\
\hline Khoram Abad & 328544 & 3300 & $99 / 55$ & $100 / 44$ \\
\hline Borujerd & $229 / 541$ & 2900 & $79 / 15$ & $126 / 33$ \\
\hline
\end{tabular}

\subsubsection{Comparative analysis of urban land per capita gross in Kashan and some existing standard scales in Iran}

The average per capita gross in the city of Kashan does not match with the existing standard scales. The average per capita gross of urban land in Iran is 39 percent, in the warm and dry cities is 41 percent; in cities composed of 100 to 250 thousand inhabitants it is 45 percent; and the recommended figure by the Housing and Urban ministry is 41 percent per capita gross land for Kashan. Table 3 shows average land per capita gross for each of the standard scales studied. 


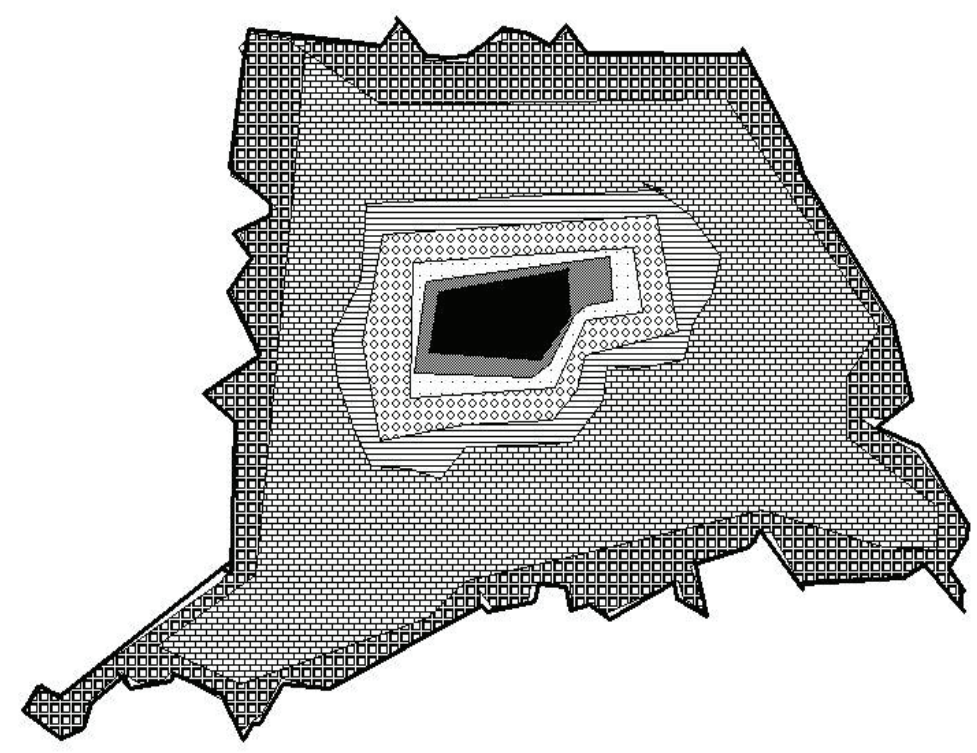

Without Units

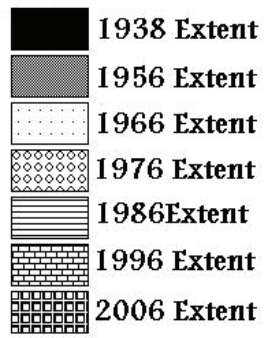

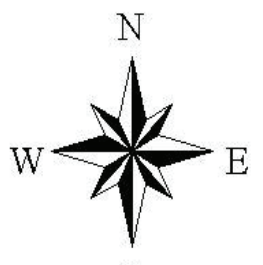

S

Figure 1: Initial extent and scope during 1938, 1956, 1966, 1976, 1986, 1996 and 2006 in Kashan [7].

\subsubsection{Comparative study of urban land per capita gross in Kashan and some cities in developing countries}

For comparative analysis of urban land per capita gross in Kashan, with some cities in developing countries, 12 cities have been selected randomly. The total population size, density of people per hectare and the average land per capita gross for each person of the selected cities are presented in table 4. 
Table 3: Average land gross per capita for each standard scale study in 2006 [8].

\begin{tabular}{|c|c|}
\hline Name & $\begin{array}{c}\text { Per capita gross land for } \\
\text { each person (square meter) }\end{array}$ \\
\hline Kashan & 241 \\
\hline Total cities in Iran & $95 / 24$ \\
\hline $\begin{array}{c}\text { Recommended figure of Housing and } \\
\text { Urbanism Ministry }\end{array}$ & 93 \\
\hline $\begin{array}{c}\text { Average number of dry and hot cities } \\
\text { The average figure for 100 to } \\
250 \text { thousand cities }\end{array}$ & 109 \\
\hline
\end{tabular}

Table 4: $\quad$ Comparison of urban land gross per capita in Kashan, compared with some cities in developing countries in 2006 [8].

\begin{tabular}{|c|c|c|c|c|}
\hline Name & Population & $\begin{array}{c}\text { The } \\
\text { extent to } \\
\text { hectare }\end{array}$ & $\begin{array}{c}\text { Density per } \\
\text { hectare }\end{array}$ & $\begin{array}{c}\text { Per capita gross } \\
\text { land for each } \\
\text { person (square } \\
\text { meter) }\end{array}$ \\
\hline KASHAN & 248789 & 600 & $41 / 46$ & 241 \\
\hline Cairo & 8000000 & 45300 & 176 & $56 / 62$ \\
\hline Damascus & 1700000 & 57300 & 29.66 & $337 / 05$ \\
\hline Kuwait & 961000 & 20000 & $48 / 05$ & $208 / 11$ \\
\hline Baghdad & 6555000 & 73400 & $89 / 3$ & $111 / 97$ \\
\hline Algiers & 1519570 & 10000 & $151 / 95$ & 66 \\
\hline Tashkent & 3786000 & 74235 & 51 & 196 \\
\hline Warsaw & 1693000 & 51700 & $32 / 75$ & $305 / 37$ \\
\hline Moscow & 10383000 & 108100 & 96 & $104 / 11$ \\
\hline Buenos & 3050000 & 30300 & $150 / 24$ & $66 / 55$ \\
\hline Aires & & & & $122 / 39$ \\
\hline Istanbul & 12574000 & 153900 & $81 / 7$ & $327 / 27$ \\
\hline Caracas & 2100000 & 47727 & 44 & $51 / 81$ \\
\hline New Delhi & 18405858 & 95863 & 93 & \\
\hline
\end{tabular}

By looking at table 4 it becomes clear that the average land per capita gross is higher in only three cities of Warsaw, Damascus and Caracas, compared to Kashan. The average land per capita gross is less in other cities studied in comparison to Kashan. The average land per capita gross in Cairo is 23 percent, in New Delhi 21 percent, in Algiers and Buenos Aires 27 percent, in Moscow 43 
percent, in Istanbul 50 percent, in Baghdad 46 percent, in Tashkent and Kuwait 81 percent of per capita gross land in Kashan.

\subsubsection{Comparative analysis of urban land per capita gross in Kashan and some East Asian cities}

For comparative analysis of urban land per capita gross of Kashan, some 12 East Asian cities have been selected randomly.

By looking at table 5 it becomes clear that: Only in Pyongyang, the average per capita gross has more land compared with Kashan. In other cities studied, the average per capita gross is lower than that of Kashan. The average land per capita gross is in Dhaka 17 percent, in Tokyo and Seoul 24 percent, in Manila 30 percent, in Jakarta 33 percent, in Taipei 42 percent, in Nanjing 49 percent, in Nagoya and Kuala Lumpur 59 percent and in Bangkok 79 percent per capita gross of land in Kashan.

Table 5: Comparison of urban land gross per capita of Kashan and some cities in East Asia 2006 [8].

\begin{tabular}{|c|c|c|c|c|}
\hline Name & Population & $\begin{array}{c}\text { The } \\
\text { extent } \\
\text { to } \\
\text { hectare }\end{array}$ & $\begin{array}{c}\text { Density } \\
\text { per } \\
\text { hectare }\end{array}$ & $\begin{array}{c}\text { per capita gross } \\
\text { land for each } \\
\text { Person } \\
\text { (Square meter) }\end{array}$ \\
\hline KASHAN & 248789 & 600 & $41 / 46$ & 241 \\
\hline Bangkok & 8161000 & 156900 & 52 & $192 / 25$ \\
\hline Pyongyang & 3255000 & 319400 & $10 / 19$ & $981 / 12$ \\
\hline Taipei & 2619000 & 27100 & $96 / 64$ & $102 / 47$ \\
\hline Dhaka & 7000000 & 30400 & $230 / 26$ & $43 / 42$ \\
\hline Seoul & 10422000 & 60500 & $172 / 26$ & 58 \\
\hline Shanghai & 19000000 & 268300 & $70 / 81$ & $141 / 21$ \\
\hline Unvocal & 2258000 & 32600 & $69 / 26$ & $144 / 37$ \\
\hline Jakarta & 8792000 & 70903 & 124 & $80 / 65$ \\
\hline Tokyo & 120000000 & 70588 & 170 & $58 / 82$ \\
\hline Manila & 10000000 & 78125 & 138 & $74 / 48$ \\
\hline Kvlalampvr & 1887674 & 27357 & 69 & $144 / 93$ \\
\hline Nanjing & 8000000 & 95000 & 84 & 118 \\
\hline
\end{tabular}

\subsubsection{The comparative analysis of urban land per capita gross in Kashan and some western cities}

For comparative analyses of urban land per capita gross in Kashan and western cities, 12 cities have been selected randomly.

The gained result from the adaptive comparison between the average urban land gross per capita in Kashan and other cities studied is that the average land per capita gross is higher in Kashan in comparison to many cities studied above. 
Table 6: Comparison of urban land gross per capita in Kashan, with some western cities in 2006 [8].

\begin{tabular}{|c|c|c|}
\hline Name & $\begin{array}{c}\text { Density } \\
\text { per hectare }\end{array}$ & $\begin{array}{c}\text { Per capita gross } \\
\text { land for each } \\
\text { person } \\
\text { (square meter) }\end{array}$ \\
\hline Kashan & $41 / 6$ & 241 \\
\hline Paris & $206 / 47$ & $48 / 43$ \\
\hline Rome & $95 / 68$ & $104 / 51$ \\
\hline Sydney & $180 / 32$ & $55 / 45$ \\
\hline London & $261 / 94$ & 38 \\
\hline Melbourne & $97 / 5$ & $102 / 56$ \\
\hline Marseille & $97 / 8$ & $101 / 3$ \\
\hline Genoa & 87 & 120 \\
\hline Munich & $93 / 7$ & 110 \\
\hline Valencia & 95 & 133 \\
\hline Belfast & $94 / 34$ & $106 / 9$ \\
\hline Rennes & 143 & 78 \\
\hline Stockholm & $65 / 45$ & $153 / 2$ \\
\hline
\end{tabular}

So that among the 52 cities surveyed there are only seven cities with more land per capita gross than Kashan and the per capita gross land in other cities are less than Kashan.

\subsection{Theoretical evaluation of the sprawl spread of Kashan}

Holdrn's model has been used for theoretical evaluation of the urban sprawl of Kashan. Holdrn's model is one of the basic models used for identifying inappropriate urban sprawl. Using this model can determine how much the city is growing due to population increase and how much the city would grow due to urban sprawl.

Holdrn has used the formula of land per capita gross in his model in such a way that we have the following equivalent:

$$
\mathrm{a}=\mathrm{A} / \mathrm{P}
$$

In this relation the net per capita gross is equal to the extent of land (A) divided by the amount of population $(\mathrm{P})$. Based on this relationship, it can be said that the total land occupied by an urban extent is (A), which is equivalent to multiplying the per capita gross (a) and population (P). In that case [9].

According to the results gained by Holdrn's model, 67 percent of city enlargement in the years between 1938 and 2006 has been achieved due to population increase in Kashan and 33 percent of the enlargement at the same period has been achieved due to the phenomenon of urban sprawl. 


\subsection{The assessment of hidden land capacities of Kashan}

To evaluate the capacity of the land in Kashan, the following formula to predict population has been used:

$$
\mathrm{t}=\left(\log \left(\mathrm{p}_{1} / \mathrm{p}_{0}\right)\right) \div(\log (1+\mathrm{r}))
$$

In the above formula $\mathrm{p}_{0}$ is the primary population, $\mathrm{p} 1$ is secondary population, $r$ is the rate of population growth, $t$ is the time when the initial population reaches the secondary population [10]. The results of the above formula are shown in Table 7

Table 7: Extent, per capita gross, and population density and optimal conditions in Kashan in 2006 [6].

\begin{tabular}{|c|c|c|c|c|c|c|c|c|}
\hline Extent & $\begin{array}{c}\text { Existing } \\
\text { population }\end{array}$ & $\begin{array}{c}\text { Extent } \\
\text { (Hectares) }\end{array}$ & $\begin{array}{c}\text { Density } \\
\text { (Hectares) }\end{array}$ & $\begin{array}{c}\text { Per capita } \\
\text { gross } \\
\text { (square } \\
\text { meters) }\end{array}$ & $\begin{array}{c}\text { Population } \\
\text { Desirable }\end{array}$ & $\begin{array}{c}\text { Optimum } \\
\text { density } \\
\text { (Hectares) }\end{array}$ & $\begin{array}{l}\text { Optimal } \\
\text { per } \\
\text { capita } \\
\text { gross } \\
\text { (square } \\
\text { meters) }\end{array}$ & $\begin{array}{c}\text { Difference } \\
\text { between the } \\
\text { per capita } \\
\text { land, with per } \\
\text { capita } \\
\text { desirable }\end{array}$ \\
\hline County1 & 39080 & $1038 / 3$ & $37 / 63$ & $265 / 68$ & 96957 & $93 / 38$ & 107 & $+158 / 68$ \\
\hline County2 & 44750 & $1080 / 4$ & $41 / 41$ & $241 / 43$ & 100877 & $93 / 38$ & 107 & $+134 / 43$ \\
\hline County 3 & 79399 & 798 & $99 / 49$ & $100 / 5$ & 74517 & $93 / 38$ & 107 & $-6 / 5$ \\
\hline County 4 & 27701 & $337 / 4$ & $82 / 10$ & $121 / 8$ & 41095 & $93 / 38$ & 107 & $14 / 8$ \\
\hline County5 & 14906 & $755 / 5$ & $19 / 72$ & $506 / 84$ & 70549 & 93/38 & 107 & $399 / 84$ \\
\hline County6 & 2600 & 1261 & $2 / 06$ & 4850 & 117752 & $93 / 38$ & 107 & +4743 \\
\hline County 7 & 2000 & 156 & $12 / 82$ & 780 & 14667 & $93 / 38$ & 107 & +673 \\
\hline County8 & 3000 & $210 / 8$ & $14 / 33$ & $702 / 66$ & 19685 & 93/38 & 107 & $+595 / 66$ \\
\hline County9 & 4751 & $193 / 9$ & $24 / 5$ & $408 / 12$ & 18106 & $93 / 38$ & 107 & $+301 / 12$ \\
\hline County10 & 28430 & $8 / 1$ & $3 / 564$ & $2 / 85$ & 757 & $93 / 38$ & 107 & $-104 / 15$ \\
\hline County11 & 2172 & $187 / 9$ & $11 / 55$ & $865 / 1$ & 17546 & $93 / 38$ & 107 & $+758 / 1$ \\
\hline Sum & 248789 & $6027 / 3$ & $41 / 46$ & 241 & 572508 & $93 / 38$ & 107 & 134 \\
\hline
\end{tabular}

The data in table 7 show that: Kashan has the capacity (with its current official limits) for a population of over 572,508 people. In other words, with the population growth rate of 2.13 percent, Kashan has the ability to accept more population in the next 30 years within the limits of its current official status and land gross per capita and desired standards of housing and urbanism ministry.

The surrounding regions of Kashan are different from each other in the acceptance of populations. Such that population acceptance in $10^{\text {th }}$ region (the city's commercial center) is much higher than the standards, while it is almost standard in the $3^{\text {rd }}$ and $4^{\text {th }}$ region. But the adoption of population in other parts is very low, such that, regions 5, 7, 8, 9 and 11 can accept more population (with current population growth rate) until the next 70,90, 92 and 105 years respectively. The most remarkable point is the amount of the population acceptance ability in region 6 . In such a way that, this area with its current population growth rate, can settle more population until the next 210 years. 


\section{Conclusion}

Urban land gross per capita in Kashan has reached from 107 square meters to 241 square meters during the last 70 years. The number mentioned is a very high figure and most of it is due to urban sprawl. Moreover, the current extent in the city is suitable for adopting a population of over 572 thousand people and sufficient land is available to the current population growth rate of Kashan up to 30 years for population settlement.

What is inferred from these results is that, while we see such lavish exploitation of the land, it seems unlikely to achieve sustainable urban development. Because creating a balanced spatial distribution of urban services in cities with urban sprawl phenomenon (such as Kashan) is very difficult. In addition, the probability of natural hazards in counties where they are irregularly shaped and population acceptance has not been reasonable is much higher than other counties.

Scientific studies conducted in Iran confirm this statement. Case studies of Japanese international cooperation agency (JICA) in Iran shows that in case of an earthquake with the intensity of 7 degrees Richter in Tehran (a city which faces the urban sprawl phenomenon) the earthquake losses will amount to 380 thousand in the early minutes (About 6 percent of the total population of Tehran) which is very high figure. More surprisingly, whereas the human toll caused by earthquake, rather than being in crowded regions and in densely populated downtown of Tehran, will be in regions 15, 14, 16, 20 and 12. The regions mentioned were among the surrounding villages of Tehran in not too far in the past or that these regions have been located in abandoned areas around Tehran. However, in recent decades due to the increased population of the city and the high costs of land and also lack of access to inlands of the city for the inhabitants with low-incomes, these lands have been changed into buildings without observing a scientific criterion and then were attached to the main body of Tehran [11].

So regarding the facts mentioned above the urban managers in Kashan, instead of focusing on urban sprawl spread which leads to the destruction of agricultural lands around the city, increased costs of transportation and fuel, increased costs of service deliveries, and consequently increased ground stock prices of the land and creates social and economic inequalities and spatial problems and increases insecurity and above all, increases casualties resulting from natural disasters with optimal utilization of available land within the current city official limitations should improve and renovate old and worn out urban buildings and increase city density logically and according to the standards to answer many of the urban needs and to provide conditions for urban sustainable development.

\section{References}

[1] Shakoi, H., Social geography of cities, University press of Jihad: Tehran, p.124, 1990. 
[2] www.edalatkhahi.ir.

[3] Mashhadi Zade Dhaqany, N., Analytical features of urban planning in Iran, Science \& Industry University: Tehran, pp.118-135, 2002.

[4] Hesamian, F., Etemad, G. \& Haeri, M.R., Urbanization in Iran, Agah Publication: Tehran, pp. 170-174, 2008.

[5] Shakoi, H., New thoughts on geography, Gita Shenasi press: Tehran, p.133, 2000.

[6] Authors calculations based on raw data Kashan municipality.

[7] Drawing from the authors based on: original maps of geographically organized Iranian Army.

[8] Authors' calculations based on: Management and planning organization, Yearbook 2007 Iranian cities, Department of statistics and information: Tehran, pp.127-200, 2007.

[9] Hekmat Nia , H. \& Mosavi, M.N,. Model application in geography with an emphasis on urban and regional planning, Elm Novin publications: Yazd, pp.131-133, 2006.

[10] Zanhani, H.A, Demographic analysis, Samt publications: Tehran, p.30, 2005.

[11] Zangi Abadi, A. \& Tabrizi, N., Tehran earthquake and evaluating spatial vulnerability of urban counties, Geographical Researches: Tehran, pp 56-60, 2006. 